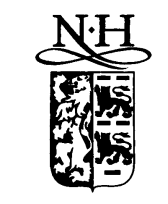

ELSEVIER

\title{
Is this the end of economic development?
}

\author{
Irma Adelman ${ }^{\mathrm{a}, *}$, Erinc Yeldan ${ }^{\mathrm{b}}$ \\ a University of California, 207 Giannini Hall, Berkeley, CA 94720, USA \\ ${ }^{\mathrm{b}}$ Bilkent University, Ankara, Turkey
}

\begin{abstract}
The paper reviews the policies and institutions used by governments that have successfully promoted economic development. It examines which policy instruments countries can still wield in the current global trading and financial regimes. It concludes that the openness and nature of short-term financial markets eliminate state use of interest and exchange rate policies while GATT/WHO eliminate trade and commercial policy. As a result, developing countries are severely limited in the means they can employ to promote development. We conclude by suggesting four reforms to increase state autonomy and lessen the frequency and severity of financial crises. (C) 2000 Elsevier Science B.V. All rights reserved.
\end{abstract}

JEL classification: 0100

Keywords: Economic development; Global financial systems; Macroeconomic policy; Economic dynamics and structural change

\section{Economic development defined}

Economic development, as distinct from mere economic growth, must combine five elements: (1) self-sustaining growth; (2) structural change in patterns of production; (3) technological upgrading; (4) social, political and institutional modernization; and (5) widespread improvement in the human condition. Prior to the end of World War Two, developing countries experienced only cycles in economic growth, not economic development. These cycles were related to the cycles in the economic growth of industrial countries. They were induced by fluctuations in the world demand for food and raw materials and were enabled by exports of capital

* Corresponding author. Fax: + 1-510-643-8911.

E-mail address: adelman@are.berkeley.edu (I. Adelman).

0954-349X/00/\$ - see front matter (C) 2000 Elsevier Science B.V. All rights reserved.

PII: S0954-349X(99)00019-3 
and skills from metropolitan centers. Economic development became possible only after the end of World War Two, when several new elements coincided: (1) for the first time, most developing countries attained political autonomy; (2) there was a flow of subsidized capital and technical assistance from developed to developing countries; and (3) the international economic environment granted developing countries an unprecedented degree of autonomy in managing their economic destinies. Currently, the process of economic development is at risk because the nature of global institutions for short term capital flows is robbing developing countries of their economic autonomy.

To understand why this is the case, we must look at how development can be induced and how, with the current exchange rate and trade regimes, the free international movement of short-term capital undermines the ability of countries to induce economic development by robbing them of even the minimal economic instruments they retain.

\section{Policies required to induce development}

First, how can development be induced? The answer to this question is essentially the same whether we look at the follower countries which developed during the Industrial Revolution or at the most successful, East Asian, practitioners of development policy after the end of World War Two. Both then and now, the state has played a central and pervasive role in the initiation development. The role of the state went well beyond establishing the economic and institutional conditions necessary to bring about the Industrial Revolution and to promote its spread, even in Britain and the United States.

Governments have used a large variety of instruments, both direct and indirect, to promote industrialization: general and targeted subsidies; tariffs; credit and direct finance; incentives; monetary policy; monopoly grants; quantitative restrictions; licensing; tax privileges; regulation of foreign investment and foreign capital inflows. Challenged by Britain's industrialization then and that of OECD countries now, governments enlarged the size of the domestic market by unifying their countries politically; by investing in inland transport; and by abolishing internal customs duties and tolls. They also added government demand for manufacturers (e.g. military uniforms in Catherine the Great's Russia) to inadequate private demand. Governments increased the supply of labor by removing legal barriers to mobility of labor among regions and sectors; by establishing favorable immigration laws and, where necessary, importing foreign skilled workers; and by investing in education. Governments increased the supply of domestic finance by promoting the establishment of investment banks (now called development banks); the formation of financial intermediaries; institutions and policies fostering the transfer of finance to industry; and, where necessary, by financing industrial enterprises themselves. Governments promoted the import of technology from advanced countries. Governments were also a source of externality for private investment. They fostered the build-up of transport infrastructure by: investing in different transport modes 
directly; providing finance for building canals and railroads then and highways, airports and ports now; granting substantial incentives, such as rights of way, for the build-up of transport by the private sector. They also invested in electricity and power and built industrial parks and free processing facilities. Governments lowered risk by enabling the establishment of limited liability companies, increasing the security of property rights, and enforcing private contracts.

Historically, governments intervened most directly and in a more targeted manner in the least developed late-comers. Of course, this required administratively capable governments with a certain degree of autonomy in setting policies, forming institutions and designing interventions.

\subsection{Korean development policy}

A more specific indication of the mechanisms employed to induce development can be obtained by looking at Korea, arguably the most successful post-war developer, where government guidance of the economy was also quite strong. Its development strategy and the mechanisms used to promote it are very similar to those used by Taiwan, and, earlier, Japan as well as to those of the 19th century late comers to the Industrial Revolution. The East Asian development process gives the lie to the 'macroeconomic policy myth' (known as the 'Washington consensus'), that the initial development of a developing economy can be adequately engineered and kept going solely through the management of macroeconomic variables, such as the money supply, budgetary deficits, interest rates and exchange rates, provided the economy's trade is liberalized and market institutions are allowed to operate internally.

When President Park came to power in 1961, he started by very quickly converting the corrupt, 'soft' state he had inherited into a developmental, 'hard' state, by transforming the bureaucracy and its incentives. He then proceeded to execute an industrial policy, using a large battery of targeted and untargeted interventions to implement his detailed vision of the public interest.

The primary development strategy employed to foster Korea's economic development has been export-led industrialization. This strategy was implemented primarily by forging a synergistic and cooperative relationship with business, in which business followed the directives of the government. The export-led growth period, which started in 1965, was preceded by a brief period of classical import-substitution, which set the stage for the export-led growth which followed. Korea's industrialization strategy emphasized rapid structural change, progressing from agriculture, first, to labor-intensive industries, followed by intermediate goods, capital-and-raw-material-intensive products, and finally by high-level-manpower-intensive industries. The export-led industrialization policies of Korea were mercantilist rather than inspired by neo-classical free-trade and were not characterized by neutral economic incentives ${ }^{1}$. Furthermore, the trade policies were never pure:

\footnotetext{
${ }^{1}$ This occurred despite Bela Balassa's numerous efforts to turn trade policy into the neo-classical ideal.
} 
the import-substitution periods, both during 1961-66 and during 1973-81, emphasized exports as well as import substitution. Conversely, selective import-substitution was also promoted even during the heyday of Korea's export-led growth from $1967-72$.

One can classify the instruments used by the Korean State to influence and direct economic activity into three major types: market and non-market incentives; discretionary and non-discretionary bureaucratic interventions; and moral suasion. The mix among types has varied over time, but at no time could Korea's institutions be described as fitting the purely neoclassical, laissez-faire mold or the purely Keynesian one.

The primary market incentives used to promote exports consisted of raising inducements for exports through a major devaluation and boosting the profitability of exports relative to imports through changes in the effective exchange rate attached to exporting. The effective exchange rate for exports was increased through a battery of largely non-discretionary measures: the allocation of subsidized credit to exporters; linking access to foreign exchange and to import licenses to export performance and allowing exporters to sell off their import licenses on a foreign exchange market; duty-free entrance of raw material inputs for export-production; a wastage-allowance system that permitted the domestic sale of some portion of the raw-materials imported for export purposes; tax and tariff rebates for exporters; and selective price controls on critical inputs and on wages. The export-incentives were detailed and commodity-specific, especially in the import-export linkage mechanisms. In practice, the specificity of the export-incentive design led to a system of multiple, commodity-specific, effective exchange rates, in which the effective government-subsidy rate varied substantially among commodities. Gradually, these incentives were reduced, effective exchange rates were unified, and, after 1980, these incentives were abolished.

Non-market, industry-specific, non-discretionary measures were used to stimulate exports as well. Government-financed institutions for export-promotion were created $^{2}$. Firms in most export-industries were afforded a sheltered domestic market in which they could sell the non-exported portion of their output at above world market prices. Initially, the domestic market was protected not only by tariffs but also by import-quotas and outright prohibition of imports ${ }^{3}$. Most of these measures were dismantled after 1980, as well.

A battery of non-market discretionary direct pressures was exerted on individual firms to expand exports or engage in (or refrain from) specific activities as well: individual firms were subjected to high and ever-rising export quotas negotiated between them and Ministry of Commerce officials. Each firm's export performance was used as the most important yardstick of its overall economic performance, and

\footnotetext{
${ }^{2}$ These consisted of the Korea Trade Association, the Korea Trade Promotion Corporation, and government-sponsored technology-oriented research institutes.

${ }^{3}$ Taiwan went even further, setting quotas and barring imports not only by commodity but also by country.
} 
hence, as a criterion for qualifying for further discretionary rewards. The export accomplishments of individual firms were closely monitored not only by the Ministry of Commerce but also by the President himself. Firms exceeding their export quota were rewarded, by incentives such as increased subsidized credit and import licenses, and administrative support. Firms falling short of export targets were punished, through discretionary measures ranging from tax audits, to cutting off utilities (!), to revocation of trading licenses.

Finally, the Korean government used moral suasion or sometimes even downright coercion to motivate economic actors to vigorously pursue its objectives. The names of good performers in the export arena and in the village movement were publicized in the mass media. Recalcitrant chaebol owners could find themselves prosecuted in court, for an unrelated offense, or simply thrown in jail.

Thus, government intervention was multifaceted, used a multitude of different instruments, and took many different guises. Korea's economic growth was not a case of simply 'getting prices right'; in addition to price policy, a multitude of market and non-market, discretionary and non-discretionary incentives was used to achieve both general and specific industrial policy goals. Neither was it a case of 'getting prices wrong'4. Rather, it represented a creative mix of prices that were almost right with subsidies, targets, directives, regulation and controls that provided just the right mix of carrots and sticks. Institutions, and market and non-market incentives were crafted so as to make cooperation by chaebols and other economic actors a matter of rational pursuit of self-interest. Of course, this is not to say that the major thrust of economic policy was always correct ${ }^{5}$. But the saving grace has been that, when close monitoring of the economy revealed that a mistake had been made, the policy apparatus had sufficient autonomy, commitment to development and flexibility to be able to quickly switch out of it.

At times, government intervention into the economy was quite heavy handed and arbitrary. Sometimes, the interventions involved blatant disregard of private property rights, both those of business and of savers, as when specific chaebols were ordered to transfer firms to other chaebols, with scant or no compensation, or when non-bank loans were frozen or private commercial banks were ordered to make unprofitable loans. At other times, government-intervention was aimed at correcting the admitted deficiencies of neoclassical economies. In those instances intervention was externality-generating or merely substituted for imperfect or missing markets, which, as with financial repression, it sometimes, consciously generated. Still at other times, government intervention was aimed at achieving legitimate non-economic objectives, such as security goals (the heavy and chemical industry drive and pursuit of self sufficiency in rice of the 1970s); national-image enhancement objectives (the heavy and chemical industry drive, hosting the Olympics, or

\footnotetext{
${ }^{4}$ Amsden (1989), argues that Korea's economic growth can be explained by this policy.

${ }^{5}$ For example, the emphasis on heavy and chemical industry development in the early seventies was premature relative to the country's comparative advantage and was initiated under (unforeseeable but) highly inauspicious international circumstances (the oil cartel and the slowdown of the world economy).
} 
joining the OECD); or distributional concerns (the village revitalization movement of the seventies, support of housing mortgages in the late eighties or successive attempts to benefit small and medium-size business). At times, government intervention increased the influence of market forces. The export orientation of the economy and successive moves to liberalize foreign trade exposed the business sector to foreign competition as a substitute for missing domestic competition. The limited attempts to liberalize capital markets, introduce competition into the financial sector, and reign in and rationalize the chaebols undertaken during the early eighties were also aimed at increasing the competitiveness of the economy. At other times, government intervention reigned in competitive forces. The repeated bailouts of the chaebols, controls on capital movements and foreign investment, and forcing particular chaebols to undertake or refrain from undertaking certain specific activities (such as building cars, or making steel) are cases in point.

At times, government intervention was market conforming in the short run, as with the movement of effective exchange rates over time during the 1960s substituting for currency devaluation. At other times it was market conforming not immediately but only in the medium to long run, as when industrial complexes were built to generate externalities. At still other times, the intervention was not market conforming at all, as with the bailouts of large conglomerates and commercial banks, but was responding to social, rather than purely economic goals, such as the need to maintain employment, or the need to maintain stability by avoiding financial crises.

At times, as with export-and-fixed-investment promotion or union-activity suppression, government intervention was generic, in the sense that all who engaged in a certain action were entitled to specified levels of support or punishment. At other times, government intervention was targeted to certain specific activities and actors. Generally, government intervention was more cost-effective when it was generalized than when it was targeted, although there are important exceptions to this statement ${ }^{6}$. During most of the 1960 s, the intervention was mostly generic but during the 1970s there was a shift to largely targeted intervention. In the 1980s and beyond, targeted intervention was greatly reduced.

The important issue, however, is not whether government intervention existed, which no one denies, but rather whether it was required in order to induce development. Would the economy have grown even faster, at a smaller economic or social cost, without it? We believe that government intervention was essential to jump-start the development process and, up to a point, to keep it going and that, without extensive government intervention during the 1960s and 1970s, Korea could not have become the economic powerhouse that it now is. After all, Korea became a success story only after the major institutional and economic-policy framework for a hard developmental state was put in place. Similar interventions also worked extremely well in the other East-Asian economies.

\footnotetext{
${ }^{6}$ The well-managed public iron and steel conglomerate, POSCO, or the private Samsung conglomerate are cases in point.
} 


\section{What degrees of policy-freedom do developing countries retain currently?}

Membership in WTO and adherence to GATT rules, which the more developed developing countries are pressured to obey, loses them most instruments of commercial trade policy. Countries cannot use tariffs and quotas, or sector-specific subsidies to promote climbing the ladder of comparative advantage. They cannot increase the effective exchange rate for exports through subsidized allocation of scarce resources, such as credit or foreign exchange or tax and tariff-rebates for exporters. The effective exchange rate for exports and imports must be the same and must be uniform across sectors. Thus WTO members lose most market, non-discretionary instruments. GATT/WTO members also lose most major nonmarket, industry-specific, non-discretionary measures: They cannot grant exporters virtual monopoly in the domestic market; if exported goods sell domestically at above export-price they are deemed to engage in dumping on the world-market. They also cannot impose export targets on firms for the same reason. Thus, by virtue of GATT/WTO, the major non-discretionary instruments that NICs retain are the macroeconomic ones, of exchange rate devaluation, setting economy-wide interest rates and wage repression. The latter, though used, has clearly deleterious effects on income distribution and social welfare. But, as we shall see below, the freedom of short-term capital movements imposes the severe penalty of recurrent financial crises on governments that actively employ exchange rate and interest rate policies in an aggressive manner, to further economic development.

True, under GATT/WTO, countries wishing to climb the ladder of comparative advantage can still use the less polite (and less efficient and more error prone?) non-market, discretionary pressures on entrepreneurs to push them to invest in particular types of factories. They can also continue to carry out direct governmentinvestment in specific public enterprises and/or court certain foreign investments ${ }^{7}$. They can also continue to generate externalities by investing in public education, research and infrastructure. But, even without free short-term capital movements, the ability of NICs to induce structural change in patterns of production and generate movement to higher-productivity activities and sectors, a major element of development, is severely curtailed.

But matters get worse. With regulated foreign capital inflows, countries could choose two out of three of the following instruments: the exchange rate regime (managed float or flexible) and, with a managed float, the exchange rate level; the interest rate level (above or below world-market); or the rate of inflation. They cannot choose all three because, as evident from the discussion below, they are interconnected. But with unrestricted foreign capital inflows, countries lose control over all three of these instruments. Governments become unable to employ their traditional macroeconomic policy instruments (interest rates, government expenditures, and exchange rates) unilaterally. Thus, raising interest rates above worldmarket levels triggers a large foreign capital inflow, setting the stage for a

\footnotetext{
${ }^{7}$ GATT/WTO does not prohibit countries from granting foreign companies some market subsidies, which it forbids them from granting domestic companies.
} 
subsequent financial crisis; there is an exchange rate appreciation; this leads to a loss of international competitiveness, decline in demand for domestic manufacturing and increase in demand for imports; this raises the trade deficit and reduces the current account surplus (phase 1 of the process). As the process continues the current account surplus is transformed into a current account deficit, which mounts persistently. Eventually, both domestic capitalists and foreign speculators lose confidence in the currency. They rapidly withdraw massive amounts of liquid capital from the domestic economy, leading to massive capital flight from domestic currency; (phase 2 of the process) and the crisis starts. The exchange rate tumbles. The burden of foreign debt service, denominated in foreign currency, escalates. There is a scramble for liquidity to service the debt and asset values tumble, as real estate prices and stock markets crash. Eventually, the corporate sector becomes illiquid and possibly even insolvent. Banks are also hit by the increase in value of their foreign debt, and decline in quality and price of their assets. A deep depression develops. Conversely, fixing interest rates below world markets, triggers a large foreign capital outflow, setting in motion the start of the crisis and initiating the second phase of the previous process. Thus, governments lose autonomy over domestic interest rate levels, unless they are willing to court a crisis, which would be foolish indeed, and destroy their previous development gains.

Similarly, under a managed-float exchange-rate regime, setting exchange rates above equilibrium levels leads to a current account deficit, as exports lose competitiveness and imports become more attractive. This raises the trade deficit and reduces the current account surplus, positioning the economy in phase 1 in the process described in the previous paragraph. An early devaluation, returning the exchange rate to equilibrium levels, could short circuit the process by restoring export competitiveness and raising the price of imports. But it is risky, because the devaluation might be taken as a signal of economic weakness and thereby precipitating capital flight and starting the crisis. In contrast, fixing exchange rates below equilibrium stimulates capital flight and investment abroad, producing the financial crisis and initiating the process of severe and prolonged depression in phase 2 of the process described in the previous paragraph.

Thus, governments cannot set their exchange rate levels without triggering a financial crisis and severe depression even under a managed float. Of course, with flexible exchange rates, countries give up the exchange rate as an instrument up front and must accept whatever exchange rate the global system generates. In addition, flexible exchange rates amplify the effects of short term international capital flows, by allowing speculation on foreign exchange markets that are excessively large ( 2 trillion of daily transactions, $\$ 800$ billion speculative); excessively liquid; excessively volatile; imperfectly informed; and subject to herd psychology.

Finally, running a budget deficit, to stimulate growth or provide social programs more generous than the international average, causes capital flight. Domestic actors fear an inflation and international actors fear devaluation, and the economy is positioned in phase 2 of the process described earlier. 
Why are financial crises so frequent now while absent in the post-war era before 1973? Largely because, in 1973, when the supply of dollars became woefully inadequate for world trade, the global financial system was changed drastically. Flexible exchange rates replaced fixed ones; and, under US and IMF pressure, open capital markets are increasingly replacing closed short-term capital markets and regulated foreign investment flows. These changes provided the environment enabling financial crises by robbing countries of their economic autonomy. Controlled short-term capital movements would short circuit the start of the process. Neither a currency appreciation unrelated to the country's competitiveness, and due solely to foreign capital inflows, nor a currency depreciation due to capital flight, could get started.

The loss of economic autonomy resulting from unregulated short term capital flows afflicts both developed and developing nations, but has more severe consequences for developing ones. Developed countries are walking an economic tightrope in which they cannot afford to run a recession, for fear of capital flight which would start the process of phase 2, but have lost the ability to use counter-cyclical policy except with multilateral agreement for the same reason. And developing countries with open and unregulated capital markets, are extremely constrained in the extent to which their governments can stimulate further development. All countries, both developed and developing, are left with economic responsibilities without instruments they can control. It is therefore hardly surprising that, periodically, governments ignore the global constraints on their economic freedoms and trigger a financial crisis and real depression. It is noteworthy that, since 1980, three quarters of the IMF's member countries, developed and developing alike, have been hit by financial crises $^{8}$.

\section{What are the policy options open to developing countries?}

So, what are developing-country governments to do in the Post Bretton Woods era? Fundamentally, governments have four types of choices. One, they can relinquish their economic autonomy and renounce their responsibilities for macroeconomic management, economic development and social policy. This is hardly an appealing, or indeed responsible, choice. Developing-country governments that want their countries to become developed cannot renounce their policy autonomy. For successful long-term economic development entails a state-led process of systematically transforming dynamic interactions between institutional change, technological progress, structural change in the economy's production profile, and international trade and domestic accumulation patterns in which the government and its policies must play a key role. To enable governments to play their fundamental developmental roles successfully, they must therefore have sufficient

\footnotetext{
${ }^{8}$ So far, the United States has enjoyed both economic autonomy and immunity from crisis because dollars are the sole global asset. But, it is about to lose that immunity once the Euro becomes a credible international currency.
} 
economic and political autonomy to shift among policy-regimes as the requirements of economic development, and as switches in domestic conditions and the international environment take place.

Two, development-oriented governments can limit themselves to the instruments they retain. In particular, having lost control over more neutral indirect means of promoting structural change, they can rely increasingly on direct, targeted and untargeted, mostly non-market mechanisms for achieving economic development. More specifically, they can use disguised subsidies ${ }^{9}$ to industry, through education, infrastructure investment, cheap food, and low-wage, anti-union policies. They can use targeted subsidies in the form of tax rebates and/or monopoly privileges to specific industries, regions and firms. (But here they may invite retaliation from OECD countries, under GATT/WHO). They can create generalized externalities in the form of investment in education, skill-import enticements, state supported research, and tax holidays to promote local and foreign direct investment. They can build the physical and legal infrastructure for processing zones and industrial parks. The less developed among developing countries, that still retain the capacity to impose infant-industry protection under GATT and WHO, can use selective tariffs to promote climbing the ladder of comparative advantage. Finally, as was done in Korea, Meiji Japan, and Communist China, they can create national commitment to development, through the educational system, the use of the media and national campaigns to motivate workers, entrepreneurs, bureaucrats and households to exert themselves and work hard, save and invest in the interest of the modernization of their countries. Of course, the national commitment route presupposes a culture that is amenable to this and a distribution of assets and access to accumulation opportunities that is relatively egalitarian.

Nevertheless, the pace of modernization developing countries will be able to achieve through the concerted (and coordinated) use of this battery of direct instruments will be much slower than it was during the Bretton Woods era. It will be constrained to a balanced-budget and relatively restrictive monetary and fiscal regime. It will likely be costly, as some of the targeted efforts may be economically inappropriate, premature, ill-timed or of the wrong scale. It will also require state-institutions for coordination of industrial policies, not unlike the development agencies of the 1960s and 1970s. This statist-capitalism approach will therefore not have much of a chance of success if the domestic political/bureaucratic environment is not capable, honest and committed to modernization. It will also require that the international environment be committed to economic growth, so that world-demand for imports from developing countries is expanding.

It is an ironic thought that this 'do what you can' approach, which is the most statist and interventionist, is stimulated by too liberal an international environment imposed on countries and economies that are not ready for endogenous growth and structural change institutionally, socially or politically.

\footnotetext{
${ }^{9}$ Open, direct subsidies are illegal under GATT.
} 
Third, developing countries can work to convince the international community that the current global financial system requires reform. Their efforts along these lines can be augmented by lobbying by development-oriented national and international aid establishments of OECD countries. International aid establishments can add their voices to those of developing-country advocates of financial reform of global short-term capital markets in the international community. As we have learned from the almost seventy financial crises during the last 15 years or so, and as pointed out by Tobin (1974), international markets for foreign exchange are too smooth, permitting the transfer of vast sums to be carried out instantaneously; they are also much too large, enabling immense amounts of cash to be brought to bear on any currency at any moment in time; and they also have an inherent tendency to overshoot, generating waves of over-optimistic risk assessments, leading to overlending, followed by over-pessimistic risk assessments, leading not only to the cessation of new loans but also to huge withdrawals of foreign currency. They are thus pro-cyclical in nature, amplifying both domestic and international recessions and prosperity. The magnitude of the problem generated by short-term international financial flows can be appreciated when one realizes that, during 1993-95, the Bank for International Settlements estimates that foreign exchange transactions averaged 1.3 trillions per day. By 1997, the daily volume of foreign exchange transactions had increased to 2 trillion! Moreover, $40 \%$ of these transactions are reversed within 2 days (and 80\% within 7 days) and are thus clearly speculative in nature. The clearly speculative volume of daily foreign exchange transactions in 1997 was thus 800 billion. The enormous swings in capital flows that ensue constitute the essence of financial crises. These crises penalize not only domestic institutional inadequacies and policy mistakes but also, the self-defeating efforts of governments to pursue policies of economic independence during the Post Bretton Woods era. No country, however large and however developed (transparent and accountable) its domestic financial institutions, is immune from currency attacks. Indeed, as pointed out earlier, of the 70 or so financial crises that have occurred lately, fully one third occurred in developed countries. There is thus common ground for agreement among developed and developing countries that reform of short term international financial markets to decrease their volatility and restrict the volume of largely speculative short term foreign exchange transactions is desirable. Iconoclastic as it may sound, some mix of regulation, disincentives, or other impediments to short-term capital mobility is required to generate a global environment that is robust and friendly to economic growth and economic development.

Note that the imposition of constraints on short-term capital movements does not require international agreement. It merely requires reducing the inordinate pressures emanating from the United States, the IMF and the OECD to liberalize trade in financial services and short term capital flows. The threat of retaliation against countries imposing barriers to financial liberalization of short term capital markets must be lifted, and that requires at least tacit international cooperation. 
Note also that we do not argue for a completely closed capital market. We do not propose imposing barriers to long-term capital flows in the form of direct investment, which is, on the whole, beneficial to domestic development. Nor are we arguing for barriers to repatriation of profits flowing from direct foreign investment. In essence, we are arguing for a return to the Bretton Woods world of constraints on short-term capital flows, including portfolio investment, combined with relatively free international trade.

Fourth, developing countries could unilaterally delink from international capital markets to preserve their economic independence and stability. They could either, like Malaysia and, Russia, eliminate convertibility of their currencies on capital accounts entirely. Alternatively, as with India and China, they could delay convertibility of their capital accounts until their economic and financial systems are sufficiently mature. Or, like Chile, they could, unilaterally, themselves introduce differential taxes and higher reserve requirements on short term capital inflows and foreign deposits, and impose controls on foreign borrowing. These measures would make it more expensive to engage in short term foreign borrowing and exchange rate speculation, and thereby provide a greater degree of state independence. But, they may also invite retaliation.

None of these classes of approaches are mutually exclusive. To our minds, the third, global-financial-system-reform approach, would be the most desirable. But it would also take longest to implement. In the meanwhile, developing countries that want to develop will have to muddle through using a mix of approaches two and four. But, unless they stay within the monetary and fiscal constraints, or unless they adopt both measures of two and four simultaneously, they will continue to suffer from periodic financial crises with devastating real consequences to the economy, to the people, and to the State.

\section{Recommendations for reform}

The recent history of financial crises in Asia, Europe and Latin America has clearly demonstrated that unregulated short-term capital markets have a social cost-benefit ratio that vastly exceeds unity. The first part of the cycle, during which the growth prospects of the economy are overestimated by the participants in the international financial markets, and foreign capital flows in and growth rises, is more than counteracted by the second, sharply declining, phase which inevitably follows. The first phase generates an increasing current account deficit and currency appreciation and slow-down in exports. When the international community starts worrying about the sustainability of the mounting current-account deficit and the consequent ability of the economy to service its ever mounting debt, which at some point it inescapably must, a precipitous withdrawal of foreign short-term capital occurs. This generates a prolonged recession that more than undoes the economic gains of the first phase of the cycle. Admittedly, the second phase of the cycle usually leads, under IMF pressure, to some long-run beneficial structural reforms in 
domestic financial systems and corporate governance. But Korea's earlier history of more gradual reforms demonstrates that, when there is social commitment to development, there are less socially costly ways of achieving these reforms.

Basically, one needs to restore an analogue to the Bretton Woods system, while maintaining some of the virtues of the liberalized trading and investment environments introduced by globalization. In any case, the forces making for liberalization of commodity and service markets (other than financial services) are too strong to be able to put the genie back in the bottle, even if one wanted to. But a modicum of economic development can still take place with that liberalization, provided the less developed among developing countries are still allowed some latitude in their trade policies. However, the liberalization of short term capital inflows and outflows threatens to bury the potential for all economic policy, macroeconomic stabilization as well as economic development. No country, however developed its financial institutions and market system can withstand the onslaught of herd psychology fueled with the hundreds of billions of liquid hot money in daily foreign exchange transactions.

The international financial system must have three basic properties: liquidity (it is the violation of this property which led to the downfall of the Bretton Woods system); stability (it is the violation of this property which is bringing down the economies of one country after another with depressing frequency and devastating consequences); and it must provide for some policy autonomy (it is the failure of the present system to provide for such policy autonomy which is plunging one country after another into financial followed by real crises.

The package of promising actions required to correct the faulty current architecture of the international financial system presented below is purposely kept minimal:

One, to provide for greater policy autonomy and stability, the US and IMF must stop pressuring countries against regulating or taxing portfolio investment, foreign borrowing, and transfers of liquid balances into or out of foreign exchange. These measures fall far short of delinking. They merely spread out in time and make less profitable international short-term capital movements. They are already being practiced by several market-oriented developing countries, such as Chile. Of course, these measures will not by themselves suffice to eliminate either real business cycles or domestically-generated financial crises.

Two, to mitigate the severity and frequency of financial cycles when conditions are ripe, the international community must require greater financial transparency of financial institutions: in OECD countries, in addition to currently provided information, banks should be required to disclose lending to hedge funds and foreign loans; and in LDCs, banks must be required to provide more accurate and timely reporting of foreign-exchange denominated obligations, foreign exchange positions and foreign borrowing, and improve bank governance. Greater financial transparency can bring about corrective actions sooner, though it too cannot, by itself, eliminate financial crises.

Three, for international-currency stability, the US must negotiate with the EU and with Japan to precommit to stable Euro-dollar and Yen-dollar exchange rates 
- the currencies of the three largest trading blocks. This is necessary to provide a stable anchor not only for these currencies but also for the domestic currencies of other countries. Once the credibility of the Euro is established, some countries will opt to peg their currencies to the Euro, others to the Yen, others to the dollar, and still others to a trade-weighted basket of these currencies. A trilateral precommitment to stable Euro-dollar and Yen-dollar exchange rates can be credible, since the US has an infinite supply of dollars while the European Monetary Union and Japan have infinite supplies of Euro and Yen, respectively, which they can use to stabilize the exchange rate. (Note that a unilateral commitment to a stable exchange rate is not enough because the US does not have an infinite supply of Euro or Yen and vice versa.) It is ominous in this context that the Euro has devalued by about $12 \%$ since its recent initiation.

Four, since even if all these proposals are implemented, financial crises will nevertheless develop, there should be some contingency planning for handling incipient crises so as to make them less devastating, once they start. At the national level, the contingency arrangements may include standby borrowing arrangements and the maintenance of larger foreign currency reserves. At the international level, one must create either a new institution, analogous to a World Central Bank, such as an expanded Bank for International Settlements or a revamped and recapitalized IMF, with the capacity to provide quick liquidity to several countries undergoing simultaneously-occurring crises.

No one of these measures taken singly will suffice to stabilize the global financial system. Even the combination of all four classes of measures will not eliminate financial crises altogether. Just as Keynesian policies do not abolish business cycles, the proposed national and international financial reforms will not eliminate financial crises either: they will merely reduce their frequency and amplitude. After all, one cannot regulate against economic stupidity; even with regulation, malfeasance can only be punished ex-post; and accidents, due to proximity to other countries undergoing a crisis or to exogenous events giving rise to a domestic recession, cannot be avoided by either domestic or international regulation. At best, all one can hope for is less numerous and less devastating financial-real cycles. But that is a goal well worth striving for.

In the near future, OECD and international aid establishments can contribute most to the economic development of developing countries not through direct capital transfers and policy advice but rather by adding their collective voices to developing country pressures for short-term global-capital-market reform. For, in the absence of reform of short-term financial markets, the effects of foreign aid are likely to be more than nullified by a succession of financial crises. The ability of foreign aid to counteract financial crises once they start is like the effectiveness of applying band-aids to stem hemorrhaging, as the annual collective amounts of resources over which aid establishments dispose is only about one eighth the value of the daily short term, speculative transactions taking place on the world's foreign exchange markets. 


\section{References}

Amsden, A., 1989. in: Asia's Next Giant. Oxford University Press, London.

Tobin, J., 1974. The New Economics one Decade Older, The Janeway Lectures on Historical Economics. Princeton University Press, Princeton, NJ. 